Annals of Warsaw University of Life Sciences - SGGW

Land Reclamation No 50 (3), 2018: 229-239

(Ann. Warsaw Univ. of Life Sci. - SGGW, Land Reclam. 50 (3), 2018)

\title{
Assessment of water quality and nutrient balance of a small lake in urban landscape - case study of Rusalka lake in the Wielkopolskie Lakeland
}

\author{
EWELINA JANICKA, JOLANTA KANCLERZ, JULITA JANY, ANNA ADAMSKA, \\ SADŻIDE MURAT-BŁAŻEJEWSKA \\ Faculty of Environmental Engineering and Spatial Management, Poznań University of Life Sciences, \\ Poland
}

\begin{abstract}
Assessment of water quality and nutrient balance of a small lake in urban landscape - case study of Rusatka lake in the Wielkopolskie Lakeland. In this work based on the results of laboratory analysis of water samples, the water status of lake and as well as water flowing and out of the lake, during growing season of 2011-2012 and 2016-2017 were assessed. The water samples for physico-chemical analysis were collected once a month from three control points and following parameter were analyzed for: oxygen conditions and organic pollutants (oxygen, BOD5, COD), acidification $(\mathrm{pH})$, salinity $(\mathrm{EC})$ and nutrients concentration $\left(\mathrm{N}-\mathrm{NO}_{3}, \mathrm{~N}-\mathrm{NO}_{2}, \mathrm{~N}-\mathrm{NH}_{4}\right.$ i $\mathrm{P}-\mathrm{PO}_{4}{ }^{3-}$ ). The state of the waters of Rusałka lake and Bogdanka river upstream the lake and downstream the lake qualified for III-V grade of quality. This was mainly due to high value of $C O D$ and $\mathrm{BOD}_{5}$ indices. The main sources of nutrients in the lake's water were the non-point sources. Yearly introduction of fish, fishing and leisure activities around lake as well as real estate development in the catchment led to the degradation of the quality of the water in Rusałka lake.
\end{abstract}

Key words: Rusałka lake, water quality, nutrient balance, degradation, eutrophication

\section{INTRODUCTION}

The problem of water status protection is a very important issue especially when the co-called Water Framework Directive is taken into consideration. The purpose of Directive is, "among other things prevents further deterioration and protects and enhances the status of aquatic ecosystems and, with regard to their water needs" (Directive 2000/60/EC). The quality of surface water is a factor affecting ecological systems, especially around urban areas, since rivers and their tributaries passing through cities receive a multitude of contaminants (Qadir et al. 2008). Urbanization, industry, agriculture, dam construction, and natural processes like erosion and climatic conditions, could each affect surface water quality (Zhang et al. 2009, Bonneau 2017).

Urban lakes, characterised as small water bodies located in cities, act as important recreation and flood regulation sites. Therefore, urban lakes are likely to be particularly susceptible to the effects of water management and human activities (Wu et al. 2014).

The quality of water reservoir depends primarily on the content of biogenic compounds and on their availability in the reservoir (Koc and Skwierawski 2004). The quality of water in dam reservoirs depends on factors: morphometric elements of the tank (surface, shape and depth), 
fluctuation of water level, time of water flow through the reservoir and quality of water flowing into this reservoir. The surface of the reservoir is important for oxygen conditions. The larger the surface, the more efficiently is a re-aeration of water. The quality of water in shallow reservoirs deteriorates more often than in deep reservoirs (Dojlido 1995). The slow flow of water through the dam reservoir changes the natural conditions in the reservoir, which become similar to the lake. Reservoirs absorb nutrients, sediments and toxins, thus reducing downstream nutrient loadings (Kõiv et al. 2011). The quality of water flowing into the reservoir may change its capacity to reduce the amount of oxygen in water or result in increased amounts of impurities (Dojlido 1995). The progressive increase of nutrients in the reservoir deteriorates water quality, ultimately leading to eutrophication (Wang et al. 2013).

The development of economic activity and intensive processes of transforming the environment affect adversely the quality of the environment. The basis for further socio-economic development is the protection of water reservoirs and proper use. The inflow of nutrients to surface waters worsens the ecological status of reservoirs (Kajak 1979).

The reasons for the degradation of water are area (mainly agricultural), point pollutants (household greywater and sewage, industrial wastewater, rainwater carried to either the lake or its tributaries through water collectors) and linear pollutants (e.g. from transport) (Chełmicki 2001).

Degradation can lead to water eutrophication, which is the result of the growth of biogenic substances in water
(Kajak 2001). Eutrophication is the most important worldwide environmental issue regarding reservoirs and many other types of aquatic ecosystems, that is characterised by high nitrogen and phosphorus loads in water bodies and results in excessive growth of phytoplankton and other aquatic plants (Schindler et al. 2008). The eutrophication process is often considered as an anthropogenic process, and the speed of process eutrophication depends on the catchment and the water reservoir (Chełmicki 2001). Enrichment of nutrients (nitrogen and phosphorus) in aquatic environment is one of the most challenging problems in water protection (Heisler et al. 2008). Pacheco and Sanches Fernandes (2016) reported lack of properly functioning sewage systems can severely damage water quality, especially in urbanized catchments. While Santos et al. (2017) reported the degrading effects of damming in rivers on catchment water quality as well as on river biodiversity.

\section{MATERIAL AND METHODS}

The results of analyzes of water sampled collected from Rusałka lake and as well as the waters flowing into and out of the lake were the basis for the assessment of water state. The water samples were taken from three measurement and control points with the frequency once a month. The data presented in this article comes from 2011-2012 and 2016-2017 hydrological years (in Poland from 01.10.2010 to 31.10 .2012 and from 01.10 .2015 to $31.10 .2017)$. The water samples were collected during the vegetation season, in three measurement and control points (the figure). 


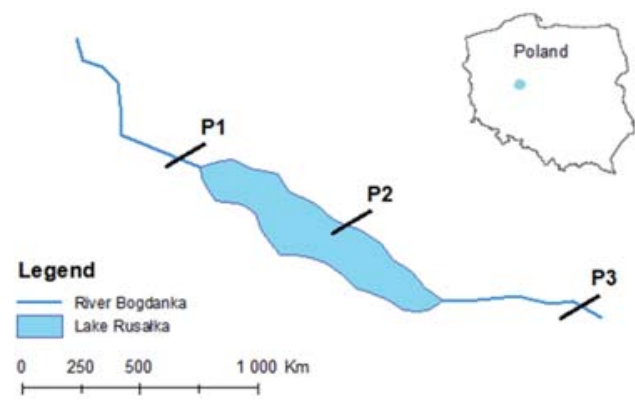

FIGURE. Location of measurement and control points: P1 - upstream Rusałka lake; P2 - Rusałka lake; P3 - downstream Rusałka lake

The direct catchment of Rusałka lake, with an area $3.21 \mathrm{~km}^{2}$ is located in macroregion Wielkopolskie Lakeland (315.5) and in a mezoregion Poznan Lakeland (315.51) (Kondracki 2011). The direct catchment of lake is the fourth order catchment, located in the Odra basin, in the Warta water region and in the Poznan Warta river basin. The catchment area is approx. $6 \%$ of the Bogdanka river catchment area, with code 18578 (Czarnecka 2005). The administrative system the direct catchments located in the central part of Wielkopolska region, in city of Poznań and makes up about $1.23 \%$ of this area.

The highest elevation in the direct catchment area is located in the northern part of the catchment $-97.5 \mathrm{~m}$ a.s.1., whiles the lowest, is located in the western part of the catchment $-68.75 \mathrm{~m}$ a.s.1. In the direct lake catchment, there are soils with medium and variable permeability of the ground (approx. 60\% of the catchment area) this affects the high density of the river network, which is $1.53 \mathrm{~km} \cdot \mathrm{km}^{-2}$. In the direct catchment area there are five water reservoirs, witch occupy $0.47 \%$ of the catchment.

The Rusałka lake is an artificial water reservoir, which was created by damming the Bogdanka river in 1943 (Pułyk and
Tybiszewska 1995). The Rusałka lake is a flow reservoir fed by the Bogdanka river (flows into the north-western part of the reservoirs, and flows out in the south-east). In addition, the lake is fed by five tributaries, the largest of them is the Golęcinka trail that flows into the lake from the north side. The four remaining watercourses flow into the lake from the south. Indicator of lake elongation rate is 4.5 , and it is in the range characteristic for Polish lakes, which is 1-25.6 (Choiński 1995, Choiński and Borkowski 2008). The maximum depth of the lake is $9 \mathrm{~m}$ and is located near the damming weir. The average depth is $1.9 \mathrm{~m}$.

Laboratory analyzes of water samples were made in the laboratory of Institute of Land Improvement, Environmental Development and Geodesy in Poznan University of Life Sciences and included determination of physico-chemical indicators characterizing: oxygen conditions and organic pollutants (oxygen, $\mathrm{BOD}_{5}$, COD), acidification $(\mathrm{pH})$, salinity (EC in $20^{\circ} \mathrm{C}$ ) and concentration of biogenic substances $\left(\mathrm{N}^{-\mathrm{NO}_{3}}, \mathrm{~N}-\mathrm{NO}_{2}, \mathrm{~N}-\mathrm{NH}_{4}\right.$, $\left.\mathrm{P}-\mathrm{PO}_{4}{ }^{3-}\right)$. The water quality class was determined according to Regulation of the Minister of the Environment of 21 July 2016 concerning the method of classification of the status of surface water bodies and the environmental quality standards for priority substances.

The nutrient balance for Rusłaka lake was calculated according to formula proposed by Giercuszkiewicz-Bajtlik (1990) and Bajkiewicz-Grabowska (2002):

$$
L_{r z}=L_{o}+\Delta L
$$

where:

$L_{r z}$ - actual annual load of nutrients delivered to the lake $(\mathrm{kg})$; 
$L_{o}$ - annual load of nutrients taken out of the lake $(\mathrm{kg})$;

$\Delta L$ - annual nutrient load accumulated in the lake $(\mathrm{kg})$.

Components of the balance (input and uptake) nutrient calculated based on the formulas proposed by Bajkiewicz-Grabowska (2002) (actual annual load):

$L_{r z}=L_{d}+L_{a}+L_{o}+L_{l}+L_{k}+L_{z}+L_{r}$

where:

$L_{d}$ - annual nutrient load delivered to the lake together with the Bogdanka river waters $(\mathrm{kg})$;

$L_{a}$ - annual nutrient load delivered with atmospheric precipitation $(\mathrm{kg})$;

$L_{o}$ - annual nutrient load delivered from sources area in the direct catchment of the lake $(\mathrm{kg})$;

$L_{l}$ - annual nutrient load delivered in the summer season by customers of the gastronomic establishment without a sanitary sewage system connection (kg);

$L_{k}$ - annual nutrient load delivered from bathers in the summer in the lake $(\mathrm{kg})$;

$L_{\mathrm{z}}$ - annual nutrient load delivered together with bait by anglers $(\mathrm{kg})$;

$L_{r}$ - annual load of nutrients brought along with stocking material $(\mathrm{kg})$.

\section{The inflow of nutrients}

Nutrient load supplied by Bogdanka river to Rusałka lake was determined on the basis of total nitrogen and total phosphorus concentrations and average water flow rates according to the formula:

$L_{d}=S Q \cdot C \cdot 86.4 \cdot 3.65 \div A$ where:

$S Q$ - average flow (Biprowodmel company data, $S Q=0.123)\left(\mathrm{m}^{3} \cdot \mathrm{s}^{-1}\right)$;

$C$ - average concentration of total nitrogen or total phosphorus $\left(\mathrm{mg} \cdot \mathrm{dm}^{-3}\right)$;

$A$ - direct catchment area with lake $\left(\mathrm{km}^{2}\right)$.

Atmospheric precipitation according to the formula proposed by Kajak (1979) and Bajkiewicz-Grabowska (2002):

$L_{a}=W_{a} \cdot A_{j}$

where:

$W_{a}$ - delivery factor for lake of nitrogen and phosphorus with precipitation: $2.0 \mathrm{~N}$ and $0.2 \mathrm{P}\left(\mathrm{kg} \cdot \mathrm{ha}^{-1}\right)$;

$A_{j}$ - surface of a lake (ha).

Non-point sources of nutrients inflow was calculated according to the formula:

$L_{o}=\left(W_{r} \cdot A_{r}+W_{u z} \cdot A_{u z}+W_{l} \cdot A_{l}+W_{z} \cdot A_{z}+\right.$ $\left.+W_{a} \cdot A_{z l}\right)(1-R)$

where:

$W_{r}$ - area flow coefficient of nitrogen or phosphorus from arable land: 10.1 $\mathrm{N}$ and $0.56 \mathrm{P}\left(\mathrm{kg} \cdot \mathrm{ha}^{-1}\right)$ (Giercuszkiewicz-Bajtlik 1990, Bajkiewicz-Grabowska 2002);

$A_{r}$-agricultural land, orchards and beach area (ha);

$W_{u z}$-area flow coefficient of nitrogen or phosphorus from grassland and wasteland: $10.0 \mathrm{~N}$ and $0.1 \mathrm{P}$ $\left(\mathrm{kg} \cdot \mathrm{ha}^{-1}\right) \quad($ Kajak 1979, Bajkiewicz-Grabowska 2002);

$A_{u z}$ - grassland and wasteland area (ha);

$W_{l}$ - area flow coefficient of nitrogen or phosphorus from forest areas: 6.5 $\mathrm{N}$ and $0.2 \mathrm{P}\left(\mathrm{kg} \cdot \mathrm{ha}^{-1}\right)$ (Giercusz- 
kiewicz-Bajtlik 1990, Bajkiewicz-Grabowska 2002);

$A_{l}$ - forest area (ha);

$W_{z}$ - area flow coefficient of nitrogen or phosphorus from built-up areas: $6.0 \mathrm{~kg} \mathrm{~N}$ and $0.9\left(\mathrm{~kg} \cdot \mathrm{ha}^{-1}\right)$ (Giercuszkiewicz-Bajtlik 1990, Bajkiewicz-Grabowska 2002);

$A_{z}$ - built-up areas (ha);

$W_{a}$ - delivery factor nitrogen or phosphorus with precipitation: $2.0 \mathrm{~N}$ and $0.2 \mathrm{P}\left(\mathrm{kg}^{\circ} \cdot \mathrm{ha}^{-1}\right)$ (Kajak 1979, Bajkiewicz-Grabowska 2002);

$A_{z l}$ - an area of the direct catchment of lake (ha);

$R$ - retention factor of nitrogen or phosphorus: $0.41 \mathrm{~N}$ and $0.573 \mathrm{P}$ (Bajkiewicz-Grabowska 2002).

The gastronomic place, which is not connected to the sanitary sewage system according to the formula:

$L_{l}=\left(T \cdot W_{l} \cdot d_{r}\right)\left(1-R_{g}\right)$

where:

$T$ - number of tourists;

$W_{1}$ - factor of nitrogen or phosphorus secretion by humans: $12.3 \mathrm{~N}$ and $1.92 \mathrm{P}\left(\mathrm{g} \cdot\right.$ day $\left.^{-1}\right)($ Kajak 1979, Bajkiewicz-Grabowska 2002);

$d_{r}$ - number of days of the tourist season;

$R_{g}$ - retention factor of nitrogen or phosphorus in the soil: 0.2 (Kajak 1979, Bajkiewicz-Grabowska 2002).

Load delivered by the bathers according to the formula:

$L_{k}=d_{r} \cdot k \cdot W_{k}$

where:

$d_{r}$ - number of days of the tourist season; $k$ - number of swimmers in the lake in one day of during the tourist season;

$W_{k}$ - factor introduced of nitrogen or phosphorus by swimmers: $1 \mathrm{~N}$ and $0.05 \mathrm{P}$ (g) (Bajkiewicz-Grabowska 2002).

Fishing baits according to the formula:

$L_{z}=L_{w} \cdot d_{w} \cdot w_{s}$

where:

$L_{w}$ - number of anglers in one day during fishing season;

$d_{w}$ - the number of days of the fishing season;

$w_{s}$ - factor introduced of nitrogen and phosphorus by anglers: $18.15 \mathrm{~N}$ and $3.27 \mathrm{P}(\mathrm{g})$ (Wołoś and Mioduszewska 2003).

Material of restocking according to the formula:

$L_{r}=M_{r} \cdot W_{m r}$

where:

$M_{r}$ - mass of material of restocking;

$W_{m r}$ - the content of nitrogen or phosphorus in $1 \mathrm{~kg}$ of fresh fish: 30 $\mathrm{N}$ or $2.1 \mathrm{P}\left(\mathrm{g} \cdot \mathrm{kg}^{-1}\right)$ (Emnadf and Muskot 2009).

\section{RESULTS AND DISCUSSION}

\section{The quality of water}

The average concentration of oxygen dissolved in water, in the studied measuring points, in 2011-2012 and 2016-2017 ranged from 7.1 to $12.80 \mathrm{mg} \mathrm{O} \cdot \mathrm{dm}^{-3}$. 
The concentration of dissolved oxygen was not lower than the minimum value according to the regulation $(6.8 \mathrm{mg}$ $\mathrm{O}_{2} \cdot \mathrm{dm}^{-3}$ ). The average content of dissolved oxygen in water decreased for the second measurement period (Table 1).

The $\mathrm{BOD}_{5}$ concentration in both examined hydrological years exceeded the threshold values given in the Polish regulations. The highest $\mathrm{BOD}_{5}$ values were observed in the Rusałka lake and in the P1 piont. The average COD concentrations also significantly (four times) exceed the standards for the II water quality class. According to the Regulation of the Minister of the Environment of 2016, the limit value for the II class quality is $10 \mathrm{mg} \mathrm{O}_{2} \cdot \mathrm{dm}^{-3}$, COD average values in the measurement points in 2010-2011 exceed value $47 \mathrm{mg} \mathrm{O} \mathrm{O}_{2} \cdot \mathrm{dm}^{-3}$ while in 2016-2017 $45 \mathrm{mg} \mathrm{O} \mathrm{O}_{2} \cdot \mathrm{dm}^{-3}$ (Table 1).

The average value of electrical conductivity for the first research period was $743 \mu \mathrm{S} \cdot \mathrm{cm}^{-1}$, and did not change in the following hydrological year studied $\left(749 \mu \mathrm{S} \cdot \mathrm{cm}^{-1} \mathrm{EC}\right.$ at $\left.20^{\circ} \mathrm{C}\right)$. The lowest values of electrical conductivity was noted for the P2 measurement point (Rusałka lake) and amoaunted $639 \mu \mathrm{S} \cdot \mathrm{cm}^{-1}$. For comparison, at the same measuring point, in the next research period, the average value of this parameter increased and amounted to $669 \mu \mathrm{S} \cdot \mathrm{cm}^{-1}$. However, comparing obtained results of EC with threshold limits for the second quality class $\left(620 \mu \mathrm{S} \cdot \mathrm{cm}^{-1}\right)$, in all cases measured values exceed this limit (Table 1).

TABLE 1. The value of selected physico-chemical parameters for 2011-2012 and 2016-2017 hydrological years

\begin{tabular}{|c|c|c|c|c|c|c|c|c|}
\hline Parameter & Period & $\mathrm{P} 1$ & $\mathrm{P} 2$ & P3 & $\bar{x}$ & Max. & Min. & $S D$ \\
\hline \multirow{2}{*}{$\begin{array}{l}\mathrm{O}_{2} \\
\left(\mathrm{mg} \mathrm{O}_{2} \cdot \mathrm{dm}^{-3}\right)\end{array}$} & 2011-2012 & 8.08 & 12.80 & 10.08 & 10.32 & 12.80 & 8.08 & 2.37 \\
\hline & 2016-2017 & 7.10 & 10.87 & 8.25 & 8.74 & 10.87 & 7.10 & 1.93 \\
\hline \multirow{2}{*}{$\begin{array}{l}\mathrm{BOD}_{5} \\
\left(\mathrm{mg} \mathrm{O}_{2} \cdot \mathrm{dm}^{-3}\right)\end{array}$} & 2011-2012 & 4.46 & 7.26 & 6.80 & 6.17 & 7.26 & 4.46 & 1.50 \\
\hline & 2016-2017 & 4.78 & 7.00 & 10.23 & 7.34 & 10.23 & 4.78 & 2.74 \\
\hline \multirow{2}{*}{$\begin{array}{l}\mathrm{COD} \\
\left(\mathrm{mg} \mathrm{O}_{2} \cdot \mathrm{dm}^{-3}\right)\end{array}$} & 2011-2012 & 41.00 & 41.60 & 48.60 & 43.73 & 48.60 & 41.00 & 4.23 \\
\hline & \begin{tabular}{|l|}
$2016-2017$ \\
\end{tabular} & 30.86 & 45.26 & 40.73 & 38.95 & 45.26 & 30.86 & 7.36 \\
\hline \multirow{2}{*}{$\begin{array}{l}\mathrm{EC} \\
\left(\mu \mathrm{S} \cdot \mathrm{cm}^{-1}\right)\end{array}$} & $2011-2012$ & 779.80 & 639.40 & 811.60 & 743.60 & 811.60 & 639.40 & 91.63 \\
\hline & 2016-2017 & 762.90 & 669.50 & 816.60 & 749.67 & 816.60 & 669.50 & 74.44 \\
\hline \multirow{2}{*}{$\begin{array}{l}\mathrm{pH} \\
(-)\end{array}$} & $2011-2012$ & 8.45 & 8.69 & 8.34 & 8.47 & 8.69 & 8.34 & 0.18 \\
\hline & 2016-2017 & 8.31 & 8.45 & 8.35 & 8.37 & 8.45 & 8.31 & 0.07 \\
\hline \multirow{2}{*}{$\begin{array}{l}\mathrm{N}-\mathrm{NO}_{3} \\
\left(\mathrm{mg} \mathrm{N}-\mathrm{NO}_{3} \cdot \mathrm{dm}^{-3}\right)\end{array}$} & $2011-2012$ & 2.46 & 2.14 & 2.66 & 2.42 & 2.66 & 2.14 & 0.26 \\
\hline & $2016-2017$ & 1.65 & 2.07 & 1.95 & 1.89 & 2.07 & 1.65 & 0.22 \\
\hline \multirow{2}{*}{$\begin{array}{l}\mathrm{N}-\mathrm{NO}_{2} \\
\left(\mathrm{mg} \mathrm{N}-\mathrm{NO}_{3} \cdot \mathrm{dm}^{-3}\right)\end{array}$} & $2011-2012$ & 0.018 & 0.006 & 0.02 & 0.01 & 0.02 & 0.006 & 0.01 \\
\hline & 2016-2017 & 0.02 & 0.01 & 0.02 & 0.02 & 0.02 & 0.01 & 0.01 \\
\hline \multirow{2}{*}{$\begin{array}{l}\mathrm{N}-\mathrm{NH}_{4} \\
\left(\mathrm{mg} \mathrm{N}-\mathrm{NO}_{3} \cdot \mathrm{dm}^{-3}\right)\end{array}$} & 2011-2012 & 0.058 & 0.004 & 0.134 & 0.07 & 0.13 & 0.004 & 0.07 \\
\hline & 2016-2017 & 0.04 & 0.02 & 0.15 & 0.07 & 0.15 & 0.02 & 0.07 \\
\hline \multirow{2}{*}{$\begin{array}{l}\mathrm{P}-\mathrm{PO}_{4} \\
\left(\mathrm{mg} \mathrm{P}-\mathrm{PO}_{4} \cdot \mathrm{dm}^{-3}\right)\end{array}$} & $2011-2012$ & 0.008 & 0.004 & 0.006 & 0.01 & 0.01 & 0.004 & 0.00 \\
\hline & 2016-2017 & 0.02 & 0.01 & 0.02 & 0.02 & 0.02 & 0.01 & 0.01 \\
\hline
\end{tabular}

$N=28$ (for each parameter). 
The average $\mathrm{pH}$ value at all measuring points did not varied. The average values of this parameter were for the first measurement period 8.47 , while 8.37 for the second (Table 1).

The average concentration of nitrate nitrogen $(\mathrm{V})\left(\mathrm{N}-\mathrm{NO}_{3} \mathrm{mg} \cdot \mathrm{dm}^{-3}\right)$ and of nitrate nitrogen(III) $\left(\mathrm{N}-\mathrm{NO}_{2} \mathrm{mg} \cdot \mathrm{dm}^{-3}\right)$ in all tested samples did not exceed the limit values for a II class, except for P1 (for $\mathrm{N}-\mathrm{NO}_{3} \mathrm{mg} \cdot \mathrm{dm}^{-3}$ ). Average concentrations of ammonium nitrogen $\left(\mathrm{N}-\mathrm{NH}_{4} \mathrm{mg} \cdot \mathrm{dm}^{-3}\right.$ ) for all measurement and control points were within the limit values for the II class of water quality $\left(0.738 \mathrm{mg} \cdot \mathrm{dm}^{-3}\right)$. according to the Polish regulation. The concentration of ammonium nitrogen varied from 0.004 to $0.15 \mathrm{mg} \cdot \mathrm{dm}^{-3}$ for all points (Table 1).

The average concentrations of phosphate $(\mathrm{V})$ for all measurement and control points did not exceed the threshold limits for the II class of water quality $\left(0.1 \mathrm{mg} \cdot \mathrm{dm}^{-3}\right)$ - Table 1 .

\section{Nutrient balance}

Calculating the nutrient balance of the lake the following parameters were included in the income side: the amount of nitrogen and total phosphate loads from the Bogdanka river inflow, atmospheric deposition of $\mathrm{N}$ and $\mathrm{P}$, non-point and diffuse sources of $\mathrm{P}$ and $\mathrm{N}$. Obtained results showed that each year to the lake around $2,253 \mathrm{~kg} \mathrm{~N}$ and approximately $124 \mathrm{~kg}$ $\mathrm{P}$ are introduced (Table 2). On the basis of these results, it was noticed that the largest supply of nitrogen and total phosphorus comes from the non-point source pollution. From the areas adjacent to the lake based on the pattern $\left(t_{o}\right)$ it was calculated that it flows $1,817.71 \mathrm{~kg} \mathrm{~N}$ and $73.55 \mathrm{~kg} \mathrm{P}$, which in the balance sheet on the revenue side constitute 80.67 and $59.27 \%$, respectively. In the nutrients balance on the inflow side, it was noticed that the Bogdanka river provided small amounts of pollution. The size of nutrient loads calculated based on the formula, assuming the concentration of the respective amounts of nitrogen or phosphorus and of the average water flow rate $\left(S Q=0.123 \mathrm{~m}_{3} \cdot \mathrm{s}^{-1}\right.$, Biprowodmel company data). $41.41 \mathrm{~kg} \mathrm{~N}$ and $0.71 \mathrm{~kg}$ $\mathrm{P}$ were delivered to the reservoir.

Our calculation showed that more nutrients were delivered to the lake than discharged. Moreover, in the basin of Rusałka lake, $2,182.52 \mathrm{~kg} \mathrm{~N}$ and $121.57 \mathrm{~kg}$ P were restored, which represented respectively approx. $97 \%$ and $98 \%$ of all nutrients introduced into the lake (Table 2).

Excess nitrogen and total phosphorus accumulate in the bottom sediments of the lake or be recycled into the biological cycle. In particular, intensive surface runoff, as well as recreational and fishing use of lakes worsened its ecological potential and significantly accelerated the eutrophication process. The research of Gołdyn et al. (2015) confirm that an important role for the trophy of Rusałka lake is the ability to retain phosphorus in the shallow part of the bottom.

Water quality is very important, water in Europe is much cleaner than a few decades ago, due to investment in sewage systems to reduce pollution from urban wastewater treatment. But pollutants from agriculture are still a major problem (EEA 2016).

Studies conducted by the Chief Inspectorate for Environmental Protection conducted in 2010-2015 show that from 493 lakes up to 315 lakes did not reach 
TABLE 2. Balance of nutrients (nitrogen and total phosphorus) for Rusałka lake

\begin{tabular}{|c|c|c|c|c|c|}
\hline \multirow{2}{*}{\multicolumn{2}{|c|}{ Specification }} & \multicolumn{2}{|c|}{ Total nitrogen } & \multicolumn{2}{|c|}{ Total phosphorus } \\
\hline & & \multirow{2}{*}{$\frac{\mathrm{kg}}{41.41}$} & \multirow{2}{*}{$\begin{array}{c}\% \\
1.84\end{array}$} & \multirow{2}{*}{$\frac{\mathrm{kg}}{0.71}$} & \multirow{2}{*}{$\begin{array}{c}\% \\
0.57\end{array}$} \\
\hline \multirow{8}{*}{ Income } & inflow & & & & \\
\hline & precipitation & 72.28 & 3.21 & 7.23 & 5.82 \\
\hline & surrounding area & 1817.71 & 80.67 & 73.55 & 59.27 \\
\hline & population & 19.19 & 0.85 & 3.00 & 2.41 \\
\hline & swimmers & 54.60 & 2.42 & 2.73 & 2.20 \\
\hline & $\begin{array}{l}\text { material of } \\
\text { restocking }\end{array}$ & 70.95 & 3.15 & 4.97 & 4.00 \\
\hline & fishing baits & 177.14 & 7,86 & 31.92 & 25.72 \\
\hline & $\Sigma$ & 2253.29 & 100.00 & 124.10 & 100.00 \\
\hline \multirow{3}{*}{ Expenditure } & outflow & 44.58 & 62.99 & 0.70 & 27.61 \\
\hline & fish harvesting & 26.19 & 37.01 & 1.83 & 72.39 \\
\hline & $\Sigma$ & 70.77 & 100.00 & 2.53 & 100.00 \\
\hline & $\Delta R$ & 2182.52 & 96.86 & 121.57 & 97.96 \\
\hline
\end{tabular}

a good ecological status, and 81 lakes were classified as lakes with poor ecological status (GIOŚ 2017).

Research by Santos et al. (2017) showed that the flow of the river through the dam reservoir changes the quality of the river. The quality of the river Sabor after the flow through the dam has significantly deteriorated. The ecological status determined from ecological quality ratios of benthic macroinvertebrate assemblages were also affected, changing from good-fair in the unaffected watercourses to fair-poor in the lakes.

Nutrients in reservoirs are mostly supplied from internal sources. They tend to accumulate in the reservoir where they become available for algae growth that can result in eutrophication (Wang 2013, Santos 2017).
The research by Kanclerz (2011) shows that the quality of water downstream the Lake Gorzuchowskie has deteriorated in terms of the majority of tested indicators in comparison with the inflow. However, on the basis of the balance made for 2006, it was found that the lake retained 3,836.7 $\mathrm{kg} \mathrm{N}_{\text {total }}(17 \%)$ and $299.7 \mathrm{~kg} \mathrm{P}$ total $(20 \%)$ in a lake. The main supplier of biogens to the lake in 2006 was the Mała Wełna river, which supplied about $45 \%$ of total nitrogen and $49 \%$ of phosphorus.

The research by Ławniczak et al. (2010) regarding Lake Tomickie indicate that the main supplier of biogens brought to the lake in 2007 was the Samica Stęszewska river, with which approximately $79 \%$ of the total nitrogen load and $59 \%$ of the phosphorus load to 
the basin were delivered. And from point sources, the largest pollutant load came from illegal discharges of sewage, which have a significant share in the supply of phosphorus to the lake.

\section{CONCLUSIONS}

The waters of Rusałka lake and Bogdanka river at the measuring points, and in both measurement periods were characterized by high $\mathrm{BOD}_{5}$ and $\mathrm{COD}$ values. The average values of $\mathrm{BOD}_{5}$ and $\mathrm{COD}$ exceed the limit for Class II water quality, this may indicate that the river waters were polluted primarily with pollutants from anthropogenic areas (for example from wastewater treatment plants, uncontrolled waste water discharges, etc.). Comparing the values of all parameters can be observed an increase in $\mathrm{BOD}_{5}$ and electrolytic conductivity. At the same time the decreased in the dissolved oxygen content in all measurements points was observed as a consequence of increasing content of organic substance in water. Bogdanka river water was qualified for ecological status downstream good. Research showed that the flow of the river through the reservoir does not improve the quality of the river in both research dates.

Land developments in the direct catchment area and recreational and fishing activity have a huge impact on the quality of water in the lake. 2,253.29 $\mathrm{kg} \mathrm{N}$ and $124.10 \mathrm{~kg} \mathrm{P}$ were delivered to the lake (the most from the surrounding area). The largest amounts of nitrogen and total phosphorus came from non-point sources. Annual restocking, fishing activity and recreation and a small gastronomy near the lake without a sanitary sewer connection have worsened the ecological potential of the waters.

\section{REFERENCES}

BAJKIEWICZ-GRABOWSKA E. 2002: Obieg materii w systemach rzeczno-jeziornych [Circulation of matter in systems of rivers - lakes]. Wydawnictwa Uniwersytetu Warszawskiego, Warszawa.

BONNEAU J., FLETCHER T.D., COSTELLOE J.F., BURNS M.J. 2017: Stormwater infiltration and the 'urban karst'A review. J. Hydrol. 552: 141-150.

CHEŁMICKI W. 2001: Woda. Zasoby. Degradacja. Ochrona [Water. Resources. Degradation. Protection]. Wydawnictwo Naukowe PWN, Warszawa.

CHOIŃSKI A. 1995: Zarys limnologii fizycznej Polski [Outline of Polish physical limnology]. Wydawnictwo Naukowe Uniwersytetu Adama Mickiewicza, Poznań.

CHOIŃSKI A., BORKOWSKI G. 2008: Wody powierzchniowe. Waloryzacja jezior dla potrzeb turystyki i wypoczynku [Surface waters. Valorisation of lakes for tourism and leisure]. In: Z. Młynarczyk, A. Zajadacz (Eds.). Uwarunkowania i plany rozwoju turystyki. Przyrodnicze zasoby turystyczne i metody ich oceny. Vol. 1. Wydawnictwo Naukowe Uniwersytetu Adama Mickiewicza, Poznań: $35-56$.

Główny Inspektorat Ochrony Środowiska (GIOŚ) 2017: Stan środowiska w Polsce. Sygnały 2016 [The state of the environment in Poland. Signals 2016]. Warszawa. Retrieved form: http://www.gios. gov.pl/images/dokumenty/pms/raporty/ GIOS_Sygnaly_2016.pdf.

CZARNECKA H. (Ed.). 2005: Atlas podziału hydrograficznego Polski [Atlas of Hydrographic Distribution of Poland]. IMGW-PIB, Warszawa. 
DOJLIDO J. 1995: Chemia wód powierzchniowych [Chemistry of surface waters]. Wydawnictwo Ekonomia i Środowisko, Białystok.

European Environment Agency (EEA) 2016: The Environment of Europe 2015. State and Forecasts. Synthesis. Copenhagen.

EMNADF J., MUSKOT E. 2009: Wielkie tabele kalorii i wartości odżywczych [Big tables of calories and nutritional values]. Muza, Warszawa.

Directive 2000/60/EC of the European Parliament and of the Council of 23 October 2000 establishing a framework for Community action in the field of water Policy. OJ L 327 of 22/12/2000.

GIERCUSZKIEWICZ-BAJTLIK M. 1990: Prognozowanie zmian jakości wód stojących [Forecasting changes in the quality of stagnant water]. Wydawnictwo Instytutu Ochrony Środowiska. Warszawa.

GOŁDYN R., DONDAJEWSKA R., BUDZYŃSKA A., KOWALCZEWSKA-MADURA K., PODSIADŁOWSKI S. 2015: Przyczyny zanieczyszczenia i możliwości rekultywacji zbiornika Rusałka [Causes of pollution and restoration capabilities of Rusałka reservoir]. In: A. Ławniczak (Ed.). Sposoby ochrony i rekultywacji jezior poznańskich. Bogucki Wydawnictwo Naukowe, Poznań: 65-78.

HEISLER et al. 2008: Eutrophication and harmful algal blooms: a scientific consensus. Harmful Algae 8 (1): 3-13.

KANCLERZ J. 2011: Wpływ Jeziora Gorzuchowskiego na jakość wód rzeki Małej Wełny [Influence of lake Gorzuchowskie on water quality in the Mała Wełna river]. Nauka Przyr. Technol. 5 (5), \#82. Retrieved from: https://www.npt.up-poznan. net/pub/art_5_82.pdf.

KAJAK Z. 1979: Eutrofizacja jezior [Lake eutrophication]. Wydawnictwo Naukowe PWN, Warszawa.

KAJAK Z. 2001: Hydrobiologia - limnologia. Ekosystemy wód śródlądowych [Hydrobiology - limnology. Inland water ecosystems]. Wydawnictwo Naukowe PWN, Warszawa.

KOC A., SKWIERAWSKI A. 2004: Fosfor w wodach obszarów rolniczych [Phosphorus in water of rural areas]. Prace Nauk. AE Wrock. 1017: 165-182.

KÕIV T., NÕGES T., LAAS A. 2011: Phosphorus retention as a function of external loading, hydraulic turnover time, area and relative depth in 54 lakes and reservoirs. Hydrobiologia 660 (1): 105-115.

KONDRACKI J. 2011: Geografia regionalna Polski [Regional geography of Poland]. Wydawnictwo Naukowe PWN, Warszawa.

ŁAWNICZAK A., ZBIERSKA J., ANDRZEJEWSKA B. 2010: Bilans biogenów Jeziora Tomickiego [Nutrient balance of Tomickie Lake]. Rocz. Ochr. Śr. 12: 861-878.

MUIRHEAD R.W., ELLIOT A.E., MONAGAN R.M. 2011: A model framework to assess the effect of dairy farms and wild fowl on microbial water quality during base-flow conditions. Water Res. 45: 2863-2874.

PACHECO F.A.L., SANCHES FERNANDES L.F. 2016: Environmental land use conflicts in catchments: A major cause of amplified nitrate in river water. Sci. Total Environ. 548-549: 173-188.

PUŁYK M., TYBISZEWSKA E. 1995: Stan czystości zbiorników wodnych badanych w roku 1994 [The state of purity of water reservoirs tested in 1994]. Państwowa Inspekcja Ochrony Środowiska, Wojewódzki Inspektorat Ochrony Środowiska w Poznaniu, Poznań.

SANTOS R.M.B., FERNANDES L.S., CORTES R.M.V., VARANDAS S.G.P., JESUS J.J.B., PACHECO F.A.L. 2017: Integrative assessment of river damming impacts on aquatic fauna in a Portuguese reservoir. Sci. Tot. Environ. 601: 1108-1118.

QADIR A., MALIK R.N., HUSAIN S.Z. 2008: Spatio-temporal variations in water quality of Nullah Aik-tributary of the 
river Chenab, Pakistan. Environ. Monit. Assess. 140: 43-59.

Rozporządzenie Ministra Środowiska z dnia 21 lipca 2016 r. w sprawie sposobu klasyfikacji stanu jednolitych części wód powierzchniowych oraz środowiskowych norm jakości dla substancji priorytetowych [Regulation of the Minister of the Environment of 21 July 2016 concerning the method of classification of the status of surface water bodies and the environmental quality standards for priority substances]. Dz.U. 2016, poz. 1187.

SCHINDLER D.W, HECKY R.E., FINDLAY D.L., STAINTON M.P., PARKER B.R., PATERSON M.J., KASIAN S.E.M. 2008: Eutrophication of lakes cannot be controlled by reducing nitrogen input: Results of a 37 year whole ecosystem experiment. PNAS 105: 11254-11258.

WANG Y., WANG P., BAI Y., TIAN Z., LI J., SHAO X., LI B.L. 2013: Assessment of surface water quality via multivariate statistical techniques: a case study of the Songhua River Harbin region, China. J. Hydro-Environ. Res. 7 (1): 30-40.

WOŁOŚ A., MIODUSZEWSKA H. 2003: Wpływ stosowania przez wędkarzy zanęt na efekty wędkowania i bilans biogenów ekosystemów wodnych [Impact of anglersň use of baits on fishing ef fects and nutrient balance of aquatic ecosystems]. Komunikaty Rybackie 1: 23-27.

WU Q., XIA X., LI X., MOU X. 2014: Impacts of meteorological variations on urban lake water quality: a sensitivity analysis for 12 urban lakes with different trophic states. Aqua. Sci. 76 (3): 339-351.

ZHANG Y., GUO F., MENG W., WANG X.Q. 2009: Water quality assessment and source identification of Daliao river basin using multivariate statistical methods. Environ. Monit. Assess. 152 (1-4): 105-121.
Streszczenie: Ocena jakości wody i bilansu biogenów małego jeziora $w$ krajobrazie miejskim - analiza jeziora Rusatka na Pojezierzu Wielkopolskim. W ramach pracy na podstawie wyników analiz laboratoryjnych próbek wody oceniono stan wody jeziora Rusałka i wody zasilającej jezioro oraz wody odpływającej z jeziora w okresach wegetacyjnych lat 2011-2012 i 2016-2017. Próbki do analiz laboratoryjnych pobierane były z częstotliwością raz $\mathrm{w}$ miesiącu $\mathrm{w}$ trzech punktach pomiarowo-kontrolnych i obejmowały oznaczenia wskaźników fizykochemicznych charakteryzujących: warunki tlenowe i zanieczyszczenia organiczne $\left(\mathrm{O}_{2}, \mathrm{BZT}_{5}\right.$, ChZT), zakwaszenie $(\mathrm{pH})$, zasolenie (przewodność elektrolityczna właściwa $\mathrm{w} 20^{\circ} \mathrm{C}$ ) oraz substancje biogenne $\left(\mathrm{N}-\mathrm{NO}_{3}, \mathrm{~N}-\mathrm{NO}_{2}, \mathrm{~N}-\mathrm{NH}_{4}\right.$ i $\left.\mathrm{P}_{-} \mathrm{PO}_{4}{ }^{3-}\right)$. Stan wód jeziora Rusałka oraz rzeki Bogdanki oceniony powyżej jeziora i poniżej jeziora i zakwalifikowano do III-V klasy jakości oraz określono mianem potencjału ekologicznego poniżej dobrego. Spowodowane to było przede wszystkim wysokimi stężeniami wskaźników $\mathrm{ChZT} \mathrm{i} \mathrm{BZT}_{5}$. Głównymi dostawcami substancji biogennych do jeziora były źródła obszarowe. Coroczne zarybianie, użytkowanie wędkarskie i rekreacyjne jeziora, a także rozwój zabudowy w zlewni bezpośredniej przyczynił się do pogorszenia jakości wody w jeziorze Rusałka.

Słowa kluczowe: jezioro Rusałka, jakość wody, bilans biogenów, degradacja, eutrofizacja

MS received 18.07.2018

MS accepted 13.08.2018

\section{Authors' address:}

Ewelina Janicka

Instytut Melioracji, Kształtowania Środowiska

i Geodezji

Wydział Inżynierii Środowiska i Gospodarki

Przestrzennej

Uniwersytet Przyrodniczy w Poznaniu

ul. Wojska Polskiego 28, 60-637 Poznań

Poland

e-mail: ejanicka@up.poznan.pl 